\title{
Üçüncü Derece Arkeolojik Sit Alanlarını Koruma: Lampsakos Kuzey Nekropol Alanı
}

\author{
Erman Aksoy ${ }^{1}$ \\ ORCID: 0000-0001-7660-1054
}

\section{Öz}

Bu çalışmada Çanakkale-Lapseki Dalyan Mevkiinde yer alan Antik Lampsakos Kenti Kuzey Nekropolü sürdürülebilir koruma bağlamıyla değerlendirilmektedir. Çanakkale Boğazına sınırdaş konumuyla kuruluşundan bugüne sürekli yerleşim alanı olan Lapseki kenti, uluslararası ulaşım ă̆ına 1915 Çanakkale Köprüsü ile yeniden bă̆lanacaktır. Bu sürecin kentle birlikte miras alanların da etkilemesi, kent çeperindeki arkeolojik sit alanlarında koruma planlamasına iome kazandırmıştır. Bu çalışmanın konusu olan koruma amaçlı imar planı da bu süreçte hazırlanmaktadır. Arkeolojik sit alanındaki eserlerin müzelere taşındı̆̆ ve günümüzde alanda herhangi bir arkeolojik kalıtın bulunmadiğı bilinmektedir. Bu nedenle üçüncü derece arkeolojik sit alanı tescil statüsündeki nekropol alanı, koruma mevzuatı hükümlerine göre; koruma planıyla inşaat öncesi sondaj kazısı yapılması koşuluyla yapılaşmaya açılmıştır. Bu durumda, farkl uzmanlardan oluşan planlama ekibi, arkeolojik mirasın sürdürülebilirliğini önemseyerek, yapılaşmaya açılabilen bu arkeolojik sit alanının sembolik değerlerle kent kimliğine ve kentin belleğine kazandırılmasın önermiştir. Böylece, mevzuata göre yapılaşmaya açılacak arkeolojik sit alanlarının ya da müzelerde sergilenen eserlerinin, kentin simgesi olarak sürdürülebilirliği öngörülmüştür.

Anahtar Kelimeler: Lapseki-Lampsakos/Çanakkale, Arkeolojik Sit Alan, Koruma Amaçlı İmar Planı, Kent Simgesi

${ }^{1}$ Dr., Gazi Universitesi, E-mail: eaksoy@gazi.edu.tr 


\title{
Protecting Third Degree Archaeological Sites: Lampsakos Northern Necropolis Area
}

\author{
Erman Aksoy ${ }^{2}$ \\ ORCID: 0000-0001-7660-1054
}

\begin{abstract}
In this study, Ancient Lampsakos City Northern Necropolis located in Çanakkale-Lapseki Dalyan Region is evaluated in the context of sustainable protection. Lapseki, which has been a residential area until today with its location adjacent to the Dardanelles Strait, will be reconnected to the international transportation network with the 1915 Çanakkale Bridge. The impact of this process on heritage sites has accelerated conservation planning in archaeological sites in the city. The conservation plan, which is the subject of this study, is also prepared in this process. It is known that archaeological artifacts have been moved to museums and there are no archaeological remains in the area today. For this reason, the necropolis area with third degree archaeological site registration status, according to the provisions of the conservation legislation; It was opened for housing on the condition that pre-construction drilling excavation was made with the conservation plan. In this case, the planning team consisting of different experts took care of the sustainability of the archaeological heritage and suggested that this archaeological site, which can be opened to construction, be added to the urban identity and memory of the city with symbolic values. Thus, the sustainability of the archaeological sites to be opened for construction according to the legislation or the works exhibited in museums as the symbol of the city is envisaged.
\end{abstract}

Keywords: Lapseki-Lampsakos /Dardanelles, Archaeological Sites, Conservation Development Plan, Urban Icon

2 Dr., Gazi University, E-mail: eaksoy@gazi.edu.tr 


\section{Giriş}

Kente ait bellek, kentlinin birbirleriyle ve kentle olan etkileşimleriyle kolektif biçimde ve bilinçli olarak zihinde saklanarak oluşturulur. Bireyin ve toplumun var oluşunda ve varlığını sürdürmesinde önemli bir araçtır. Kentin belleğinin kent kimliğinden beslenmesi, kent ve kentli kimliğinde belleğin etkin olması bu iki olgunun karşılıklı etkileşimini açıklamaktadır (Al, 2011; Doğu, Deligöz, 2017). Kent kimliği sadece üç boyutlu yapılı ve doğal öğelerle değil insanın alg1-sezgi ile kavradığı, bilgi, deneyim ve kültürüyle çok yönlü değerlendirdiği unsurlarla ve gizli/açık mesajlarla, şifrelerle bir bütündür. Kentte kurulduğu günden bugüne yaşanan her sosyal ilişki, mekânın belleğine eklemlenerek yer' in ruhunu (genius loci, the spirit of place) oluşturup kentsel belleği güçlendirir (Ringas, vd., 2011; Ünlü, 2017). Dolay1sıyla kentin ruhunu ve/veya kimliğini besleyen bu değerlere ilişkin mekân ve semboller kentsel belleğin oluşmasına olanak sağlamaktadır. Bellekte yer eden ve kişisel özelliklerle duyumsal ve deneyimsel olarak farklı algılanan mekân ve semboller imgeye (simgeye) dönüştürülerek içgüdüsel olarak anlamlandırılır, sahiplenilir ve böylece aidiyet de oluşur. Bu sarmal ilişkide mekân, kenti oluşturan herhangi bir kamusal alan, sokak ya da anitsal ya da estetik değeri olmayan herhangi bir yapıdan oluşabilir. Sembol ise kentlilerin ait olma duygusuyla, birlikte yaşarken anlam yükledikleri im veya işaretlerdir. Bu nedenle sembol, kendi dışında bir nesne, ilişki, değer veya önermenin yerini alarak, kentin belleğinde depolanmış bir anıya, tarihi bir objeye hatta arkeolojik bir kalıntıya referansla kenti simgeleyen öğeye dönüşebilir.

Arkeolojik miras, yer' in ruhunun önemli bir bileşeni olarak, bulunduğu kentin birikimlerini aktarıp kentliye geçmişini, köklerini anlama ve tarihiyle yaşama ayrıcalığını sunar, saygınlık ve tanınırlık kazandırır. Arkeolojik kalıt yapısal durumuna ve potansiyellerine göre kentle sosyal, ekonomik, işlevsel, estetik, görsel ve fiziksel olarak bütünleştirilebilir ve böylece hafıza, kimlik ve aidiyet pekiştiren ve/veya yer'in ruhunu zenginleştiren değerlere dönüştürülebilir. Arkeolojik mirasın bulunduğu yerde (in situ) korunması ilkesiyle, temsiliyet gücünü artırarak tüm insanların görüş ve bilgisine açmada görsel ve anlamsal bütünlügü ve geçmişte kentin simgesi olan bazı figürlerin de aynı amaçla sürekliliği sağlanabilir.

21. yüzyılla süregiden miras değerlerini korumadaki gelişmeleri benimseyen ve bu konudaki sözleşmelere taraf olan Türkiye'de; arkeolojik, kentsel arkeolojik ve arkeolojik değerlerin bulunduğu karma sit alanlarının sürdü- 
rülebilirliğinde diğer sit alanlarında da olduğu gibi koruma plan(lar)1 esastır ve bu konu yasal hükümlerle tanımlıdır. 2863 sayılı Kültür ve Tabiat Varlıklarını Koruma Kanunun 8. Maddesine (Ek-14.07.2004, 5226/1md.) göre; kültür ve tabiat varlıklarının sürdürülebilirlik ilkesi doğrultusunda korunmasında katılımcı alan yönetimi modellerini içerecek koruma amaçlı nazım ve uygulama imar planları hazırlanmaktadır. Yaklaşık 6000 yıl sürekli yerleşim alanı olan Anadolu'da arkeolojik kalıntıları belirleme güçlüğü nedeniyle bu değerler Antik Lampsakos Kentinde de olduğu gibi genellikle inşaat faaliyetleriyle tesadüfî olarak ortaya çıkarılmaktadır. Bu çalışmada, üçüncü derece arkeolojik sit alanı statüsündeki Antik Lampsakos Kenti Kuzey Nekropol Alanı Koruma Amaçlı İmar Planı (KAİP) üzerinden bugüne arkeolojik miras değerlerinin sürdürülebilirliği, güncel-yenilikçi yaklaşımlarla değerlendirmektir. Bu yaklaşım, 2008 tarihli Québec Deklarasyonunun (Quebec Declaration on the Preservation of the Spirit of Place) "sürdürülebilir kalkınmay1 sağlayacak yenilikçi ve etkin bir yol olarak somut (sitler, binalar, rotalar, vb.) ve somut olmayan (anılar, anlatılar, gelenekler, renkler, vb.) miras birlikte korunur" (ICOMOS, 2008) ve ayn tarihli Brezilya Deklarasyonunun (Brasil Declaración De Foz Do Iguaçu) “yer' in ruhu somut ve somut olmayan kültürel bileşenlerle oluşur ve korunur" öngörülerine (ICOMOS- Brasil, 2008) dayanmaktadır. Böylece, çalışmanın kapsamında alanın tarihi ve kültürel değerleri, arkeolojik mirasın bulunduğu yerde maddi-somut ve manevi-somut olmayan (physical and spiritual) bileşenleriyle birlikte korunması (Corfield, 2014) ve koruma planlaması sürecinin önkoşulu olan alanın tanımlanması ilkelerine göre öncelikle ele alınmıştır. Sonrasında, alana ait koruma imar planının hedef ve stratejileri sürdürülebilir koruma yaklaşımıyla sorgulanarak, çağdaş kente hangi araçlarla bütünleştirilebileceği değerlendirilmiştir. Sonuçta, üçüncü derece arkeolojik sit alanında günümüze ulaşmayan ancak varlığı bilinen değerleri, ortaya çıkarmada, kent kimliğini ve belleğini güçlendirecek araç olarak değerlendirmede planlamanın fırsat yaratabileceği belirlenmiştir.

\section{Planlama Alanı: Lampsakos Kenti, Kuzey Nekropol Alanı}

Edirne Kültür ve Tabiat Varlıklarını Koruma Bölge Kurulunun 27.06.1997 tarih 4012 sayılı kararı ile Çanakkale İli Lapseki İlçesi Dalyan Mevkiindeki inşaat çalışmaları sırasında bulunan mezar kalıntılarının bulunduğu alan Antik Lampsakos Kenti'nin nekropolü olduğu kabul edilerek üçüncü derece Arkeolojik Sit Alanı ilan edilmiştir (Şekil 1). Çanakkale Kültür Varlıklarını 
Koruma Bölge Kurulu tarafından 24.02.2014 tarih ve 1417 sayılı karar ile bu alanın koruma derecesi değiştirilmeden, sınırı kadastral haritaya işlenerek kesinleştirilmiştir.

\section{Tarihte Antik Lampsakos- Lapseki Kenti}

Antik Lampsakos kentinin, Luwi-Pelasg dilinde 3 "boğaz halkının yeri" anlamındaki bu adı, Osmanlı Döneminde Lapseki olarak değiştirilmiştir. Strabon, Lampsakos kentine Bithynia-Mysia bölgesinde yaşamış Trak ve Frig karışımı Bebryklerin Kralı Mandros'un kızı Lampsake'nin adının verildiğini belirtmiştir. Strabon ve antik yazar Plinius'a göre kentin kurulduğu dönemdeki diğer adı Pityussa (Pityoussa) idi (Körpe, 2008: 385; Strabon, 2005). Diğer bir söylenceye göre bu yerleşim alanında Çam ağaçları bol olduğu için Homeros'un kenti Pityeia/ Pityusa olarak adlandırmış olmasıdır (Arslan, 2007). Evliya Çelebi'ye (1611-1689) göre kentin adı Lop adı verilen incir ve seki kelimelerinden yani Lopseki'den üretilmiştir (Evliya Çelebi, 2001).

Lampsakos, Propontis (Marmara Denizi) ile Aigaion (Ege Denizi) arasinda yer alan Hellespontos'un (Çanakkale Boğazı) Anadolu kıyısında, Marmara Denizine doğru daralan son noktasında, Critote'yu (Gallipolis, Gelibolu) karşısında, batısında Abydos (Abidos) ${ }^{4}$ ve doğusunda Parion ${ }^{5}$ kentleriyle sınırdaş konumda, bugünkü Lapseki kent yerleşiminin kuzeydoğusunda (Şekil 1), bu coğrafyadaki diğer Miletos kolonileriyle birlikte M.Ö. 7. yüzyıl başlarında kurulmuştur. Kentin kuruluşuyla ilgili farklı görüşlere rastlanmaktadır. Strabon'a göre Lampsakos, M.Ö. 670 yıllarında Miletosluların Boğazlarda, Marmara ve Karadeniz'de kurdukları ticaret kolonileriyle eşzamanlı kurulmuştur (Strabon 2005). Roma tarihçisi Eusebios'a $^{6}$ göre bu yerleşim Roma Kralı Tullus Hostilius' döneminde M.Ö. 654"te kurulmuş ve Phokaialılar (antik Foçalılar) iskân ettirilmiştir (Carriker, 2003).

3 M.Ö. 3000'li yıllarla Karlar ve Lelegler ve Pelasglar, Hattilerle akraba ve aynı soydan olan Ege'nin en eski halkıydı (Özveri, 2005; Umar, 1999).

${ }^{4}$ Abydos, Çanakkale'nin 6 km. kuzeyinde, boğazın en dar yerindeki Nara Burnu'nda M.Ö. 7. yüzyılda kurulmuştur. Kent ilk kez, Homeros'un İlyada adlı eserinde Troialılar'la Akha'lılara karşı savaşmış, hızlı atlarıyla ünlü bir yerleşim olarak anılmıştır. Ancak, en son yapılan (1885-1890 arasında) araştırmalarda kıyıda temel kalıntıları, çatı kiremitleri ve seramik parçalarından başka bir kalıntı bulunmamıştır (Tolun, 2012).

${ }_{5}^{5}$ Parion kenti, Biga'da Abydos kenti ile eşzamanlı (M.Ö. 7. yüzyıl) kurulmuştur. Büyük İskender sonrasında Helen, daha sonra Bergama Krallığı ve Roma hâkimiyetine girmiştir (Tolun, 2012).

${ }^{6}$ Caesarea'lı Eusebios ya da Eusebius Pamphili (263-339) Hıristiyanlığın ilk yüzyıllarını anlatan Caesarea Palestinae ya da Maritima (bugünkü Haifa) Piskoposu (314), Hıristiyan yorumcusu, polemisti ve tarihçisi (Grant, 2006). 
M.Ö. 6. yüzyıl ortalarında Lampsakos, diğer Batı Anadolu yerleşimleriyle birlikte Lydia Krallığının himayesindeydi. M.Ö. 546'da Lydia Krallığ Pers hâkimiyetine girmiş ve Troas bölgesiyle ${ }^{7}$ birlikte kent, Daskyleion (Kral Daskylos'un yeri, bugünkü Bandırma'nın güneyi) merkezli kurulan Phrygia Hellespontine Satraplığına bağlanmış ve Pers yanlısı tiranlar tarafından yönetilmiştir (Bakır, 2003; Buruldağ, 2017). Kent M.Ö. 511'de İyonya (Ionia) ihtilalinde Lampsakos'a sonra Perslere sığınan Atina Tiranı Hippias'a şarap üretimi için bağışlanmıştır. M.Ö. 464'de Pers Kralı Kserkses (M.Ö. 466/450) üzüm bağlarını genişletmesi için Themistokles'i kente tiran olarak atamıştır. Bu dönemin Lampsakos sikkelerindeki üzüm ve şarap kapları figürleri bu bilgiyi doğrulamaktadır (Körpe, 2011; Nemutlu, 2019). M.Ö. 453-428 yılları arasında kent, Batı Anadolu'daki Attika-Delos Deniz Birliğine (Polisleri) katılmıs, M.Ö. 411'de ayrılmıştır (Thukydides, 1976). M.Ö. 405'de Spartalı Lysandros ve M.Ö. 356 Atinalı Khares'in kenti ele geçirmiştir. M.Ö. 342'de tekrar Pers egemenliğine girmiştir (Aslan, 2007). M.Ö. 334'de Büyük İskender, Pers egemenliğini sonlandırmış ve kente Makedon göçmenleri yerleştirmesiyle kent alanı genişletilmiştir. Bu nüfus hareketlerine karşın 1. yüzyılda kent Tunç Çağlarından sonraki en düşük nüfusa sahip olmuştur. M.Ö. 310'da Lampsakos, Troas kentleri federasyonuna üye olmuş ve şenliklerde, spor yarışmalarında etkin olmuştur. M.Ö. 302'de kentlilerin rızasıyla, kent Büyük İskender'in komutanlarından Lysimachos'un yönetimine, Lysimachos ölünce M.Ö. 281'de Seleukos Krallığı'nın, M.Ö. 227'de Pergamon (Bergama) Krallığı'nın egemenliğine girmiştir. M.Ö. 218'de Kral I. Attalos (M.Ö. 241- M.Ö. 197) Seleukos kralı III. Antiokhos (M.Ö. 223-187) kente saldırınca Romalılardan yardım istemiş ve Romalılarla Seleukoslular arasında M.Ö. 188'de yapılan Apameia (Dinar) Anlaşması ile Lampsakos'a Pergamon'a bağlı otonom kent statüsü verilmiştir. M.Ö. 170'de Roma'ya bu statünün anısına altın bir çelenk gönderilmesi kentin varsıllığını ifade etmektedir (Orhun, 2018; Ramsay, 2015).

\footnotetext{
${ }^{7}$ Bugünkü Çanakkale İlinin Anadolu yakasının kuzeybatısındaki bölgeye (Biga Yarımadasına) M.Ö. 1. binde Troas adı verilmiştir. Güneyde Ege Denizi, kuzeyde Marmara Denizi ve Çanakkale Boğazı, batıda Kazdağı, doğuda Mysia (Gönençay Irmağının denize döküldüğü yerden Olympos'a kadar olan bölge) ve kuzeyde Edremit Körfezini kapsayan alan Troas bölgesidir (Orhun, 2018; Polat Becks, 2015; Yüksel, 2012).
} 


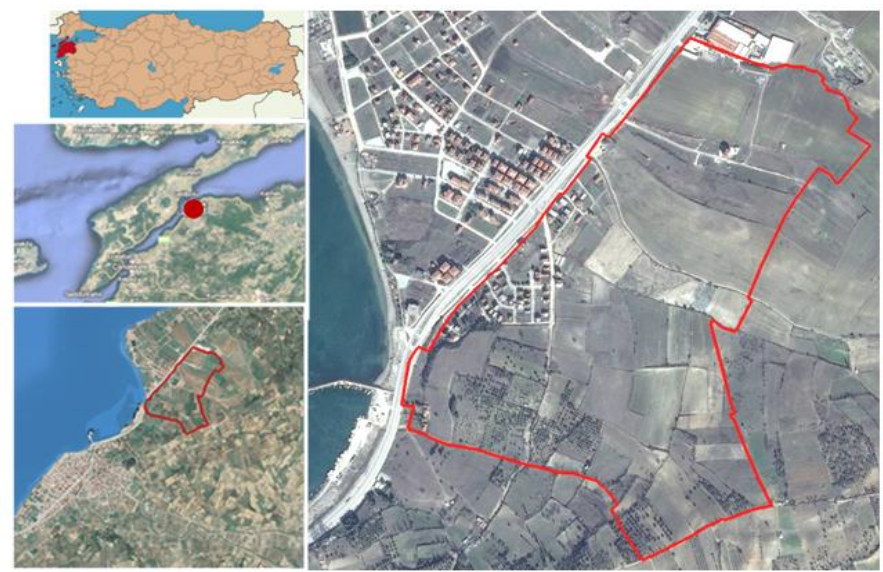

Şekil 1. Antik Lampsakos (Lapseki) Kentinin ve Kuzey Nekropol (Üçüncü Derece Arkeolojik Sit) Alanının Konumu (KAİP, 2019)

Lampsakos, sahip olduğu doğal limanla deniz ticareti ve zengin Pegai (Biga) Ovası ve İç Troas bölgesine Abydos'tan Kyzikos'a (Nara Burnundan Erdek'e) bağlanan antik yol üzerindeki konumuyla ticaret, tarım ve deniz ürünleri, tersane ve krallara özgü erguvan boya işletmeleri, altın ve gümüş madenleriyle Hellenistik dönemde Troas'in en zengin kenti durumundadır. 1996-1997'de yapılan arkeolojik kazılarda bulunan altın yüzük, çelenk, sikke ve aplik parçaları, kentin Troas'da önemli altın işleme ve üretim merkezi olduğunu belirten antik yazarları doğrulamıştır (Körpe, 1998). Özellikle Karadeniz'den getirilen buğdayın dağıtım merkezi olduğu, bu ağın Atina Kenti ile Delos ${ }^{8}$ ve Khios (Sakız) Adalarındaki ticaret acenteleriyle desteklendiği bilinmektedir. Lampsakos kenti, eşzamanlı olarak kültürel açıdan da gelişmiştir. Döneminin en önemli astronomu, matematikçisi ve doğa felsefecisi İyonyalı Anaxagoras (M.Ö. 500- M.Ö. 428) ${ }^{9}$ ve Filozof Epiküros (M.Ö. 341-M.Ö. 270) ${ }^{10}$ gibi devrinin çok önemli bilim adamlarına da ev sahipliği yapmıştır. Anaxagoras sürgün olarak geldiği kentte kurduğu okulda Epiküros da ders vermiştir (Yüksel, 2010). Antik Yunan Klasik (M.Ö. 480-330) ve Helenistik (M.Ö. 330-30) dönemlerde Lampsakos'un Miletos kenti ile tica-

\footnotetext{
8 Adını günümüze değin taşıyan Delos Adası, Yunan takımadalarından Mikenos (Mykonos) Adasının yanındaki küçük bir adadır. İyonyalılar'ın burada yaşadığı düşünülmektedir. Efsanelere göre Leto, Artemis ve Apollon'u burada doğurmuștur.

${ }^{9}$ Anaxagoras, hylozoist (varoluş sürecini arkhenin -toprak, hava, su ve ateş gibi dört temel elementincanlılığı ile açıklayan) değil, mekanist (oluşta canlılığı değil hareketi merkeze alan) bir dünya görüşüne sahiptir (Skirbekk ve Gilje, 2006).

${ }^{10}$ Epiküros, teorik olmaktan çok pratik kaygıları olan felsefesini kanonik, fizik ve etik olarak üçe ayırmıştır. Adını alan Epiküros felsefesinde ruh: ateş, soluk, hava ve adlandırılamayan (ruhsal olan) dördüncü bir öğeden oluşur (Skirbekk ve Gilje, 2006; Takaoğlu, 2007).
} 
ret ilişkileriyle üst düzey refah düzeyinin İyonyalı düşünür veya doğa bilimcileri çekmesi, kentin Troas bölgesinde en ünlü bilim ve felsefe merkezi olmasını sağlamıştır.

Lampsakos, M.Ö.133'de Roma İmparatorluğunun M.Ö. 129'da kurulmuş olan Provincia Asia'nın (Asya Eyaleti) yönetimine girmiş ve yaklaşık 300 yıl bu statüde kalmıştır. Bu süreçte kente, kısa sürelerle (M.Ö. 80-79 ve M.Ö. 74-62) Pontus Krallı̆̆ egemen olmuştur. Bölgenin nüfusunu artırma politikaları Romalılar döneminde de sürdürülmüş, Abydos, Parion gibi diğer Troas kentleriyle birlikte Lampsakos'a da emekli Romalı lejyonerler yerleştirilmiştir. Bu bölgede, Romalı senatörlerin mülkiyetinde olan ovalar köle emeğine dayalı çiftliklerle donatılmış, yetiştirilen hububat, haşhaş, üzüm ve şarap Lampsakos limanından ihraç edilmiştir. Pax Romana döneminde ${ }^{11}$ Troas'daki kentler gibi Lampsakos kentinde de halkın sevgisini kazanmak, önemli kamu görevlerine gelebilmek için gösteriler düzenlenmiş, imar faaliyetlerine öncelik verilmiştir. Ancak, 3. yüzyılın ortalarında Lampsakos da Got akınlarıyla küçülmüş ve İmparator Decius (Dakyanus) döneminde (249-251) Hıristiyan zulmüyle neredeyse köye dönüşmüştür (Körpe, 2011, Thorpe, 2002).

395'de Roma İmparatorluğunun bölünmesiyle kent, Doğu Roma (Bizans) İmparatorluğunun egemenliğine girmiştir. Bu dönemde kent, aynı adla anılan -bugünkü Musa Çayı etrafındaki- ovanın yaklaşık $50 \mathrm{~m}$. kuzeydoğusunda yükselen tepenin batı ve güneybatı yamaçlarında kale kenti olarak yeniden yapılandırılmıştır. İmparator Konstantios (337-361) döneminde Miletli Parthenios'un kentte kilise inşa ettirdiği ve kentin piskoposluk merkezi olduğu bilinmektedir. 471'de İmparator Justinianus'un, boğazın kontrolü için Gallipolis'i tahkim etmesi, tersaneler kurmasıyla bu kent yeni bir merkez olarak gelişmiş ve Lampsakos ticari önemini kaybetmiştir. Abydos kentinin, Piskoposluk merkezi olması ve gümrük teşkilatının kurulmasiyla ticareti kontrol etmesi bu durumu hızlandırmıştır. Kent 7. yüzyılın ilk çeyreğinde önce İmparator Heraclius döneminde (610-640) Opsikion Themasına $^{12}$ ve bu themayı İmparator Basiles' in (985-1025) bölmesiyle (9851025) Abydos Themasına bağlanmıştır. 4.Haçlı Seferleri sonunda Haçlıların egemenliğine giren kent, Bizans Kralı İonnes III Vatetzes (1222-1254) tara-

\footnotetext{
${ }^{11}$ Latince Roma Barışı anlamındaki Pax Romana döneminin, İmparator Augustus'un M.Ö. 27'de Roma İç Savaşını bitirişiyle başlayan ve İmparator Marcus Aurelius'un (M.S. 180) ya da oğlu Commodus'un ölümü (M.S. 192) ile sona erdiği kabul edilir (Thorpe, 2002).

12 Thema kelimesi ordu birliği manasına gelmektedir (Keçiş ve Güneş, 2018).
} 
fından İznik Devleti'ne bağlanmış ve Hıristiyan dünyasının piskoposluk merkezlerinden biri yapılmıştır (Türker, 2008).

Lampsakos kenti, 1296'da Karesi Beyliği'nin Orhan Bey döneminde (1324-1362) Osmanlı Beyliği'ne geçmesiyle Osmanlı topraklarına katılmıştır. Kentin tîmar olarak verildiği Süleyman Paşa, Lapseki kıyısında Cenevizli mimar Salcruzo de Negro'ya inşa ettirdiği büyük burcun (burgaz, bergos) Bizans dönemindeki Lapseki kalesinin bir parçası olduğu düşünülmektedir (Dukas, 2008). Osmanlı Padişahı 1. Murat döneminde (1365-1389) Yeniçeri Ocağı kurulunca, 1362'de ilk kez Gelibolu'da bu ocak için Acemi Ocağı kurulmuştur. Bu ocağın gençlerinin, Gelibolu ile Lapseki ve Çardak arasındaki gemilerde yevmiye karşılığında çalıştırılmış (Halaçoğlu, 1995) olması, Lapseki'nin 14.ve 15. Yüzyıllarda, yakınındaki Çardak ile birlikte Avrupa'ya geçişte önemli bir liman olduğu anlaşılmaktadır. I.Mehmet (Çelebi) döneminde (1413-1421) 1416'da Marmara Adasiyla Gelibolu arasında Venediklilerin kazandığı deniz savaşından bir yıl sonra Lapseki Kalesi tahrip edilmiştir (İnalcık, 2005). 1430'da kente saldıran Venediklilerle Lapseki'de barış görüşmeleri yapılmış ve aynı yıl kale temeline kadar yıktırılmıştır (Uzunçarşılı, 1982). Yıldırım Bayezid (1389-1402) boğaz muhafızlığını Gelibolu'da kurup Sarıca Paşa'yı komutan olarak ataması (1390) ve Kanuni Sultan Süleyman (1520-1566) döneminde Kaptan Paşa Eyaleti yapılmasıyla Gelibolu'nun askeri ve ticari önemi daha da artmış ve bu durumda Lapseki kenti önem kaybetmiştir (Uysal, 2013). Bu dönemde Lapseki kazası, Anadolu Eyaleti'nin Biga sancağına bağlıyken, 19. yüzyıl ortalarına kadar merkezi Gelibolu olan Cezâyir-i Bahr-i Sefîd vilâyetine, 1888' den sonra tekrar Biga sancağına bağlanmıştır (Korkmaz, 2005).

Osmanlı Döneminde kent nüfusunu genelde Müslüman Türklerle birlikte Hıristiyan ve Yahudiler oluşturmuştur. 18. yüzyılda Helen, Bulgar, Ermeni, Yahudi, Grek, Ortodoks, Müslüman ve Kıptilerin bir arada yaşadığ 1 ve kentin konumuna bağlı olarak sürekli göç aldığı bilinmektedir. 19. yüzyılın sonlarından itibaren 1876-1878 Osmanlı-Rus Savaşı sonrasında Kafkaslardan, 1912-1913 Balkan Savaşları sonrasında Yunanistan, Bulgaristan ve Romanya'dan göç almıştır. Cumhuriyet Döneminde, Lozan Antlaşmasıyla Yunanistan ve Girit'ten, 1928-29'da Surbistan ve Bulgaristan'dan, 1934-36'da Arnavutluk, Bulgaristan ve Romanya'dan, 1942'de Yunanistan'dan, 1950 ve 1987'de Bulgaristan'dan gelen Müslüman Türklerin bir kısmı Lapseki'ye yerleştirilmiştir (Tuna, 2014). Bu göçlerle 1894'te Lapseki kaza merkezinin nüfusu; 1230 kişi Müslüman, 725 kişi Rum, 28 kişi Ermeni ve 17 kişi Yahudi olmak üzere 2.000 kişidir (Cuinet, 1894). 1896'da nüfusun değişmediği ve 
kentte büyük bir ticaret merkezi (165 dükkân, 2 han, 8 hamam, 10 değirmen, 25 fırın, vb.) bulunduğu bilinmektedir (Oğuz ve Korkmaz, 2018). Ancak, 17. yüzyıldan itibaren kentin ekonomisi ticarete değil deniz ulaşımına, tarım ve hayvancılı̆̆a bağlıdır.

Çanakkale Savaşlarında, stratejik konumu ve menzil dışında kalmasıyla, 1914 yılı itibariyle lojistik merkeze dönüştürülen kentte 300 yataklı hastane ve kent dışında bir hayvan hastanesi kurulmuş, Gelibolu'daki erzak ve cephane depoları ve 5. Ordu Menzil Müfettişliği Lapseki'ye taşınmıştır. 22 Haziran 1920'deki Yunan işgali 25 Eylül 1922'de sonlandırılmıştır. 1920'li yıllarda kentin nüfusunun -antik dönem nüfusu kadar- yaklaşık 4000 kişi olduğu tahmin edilmektedir. Cumhuriyet döneminin ilk nüfus sayımı olan 1927 sayımında kaza nüfusu 18458 (8 811 erkek, 9647 kadın) kişidir (Oğuz, Korkmaz, 2018). Lapseki İlçe merkezinin 2019 nüfusu 13.818 (6937 erkek ve 6.881kadın) kişidir (Türkiye Nüfusu, 2020). 1915 Çanakkale Köprüsünün kazandıracağı ivme ile ilçenin nüfusunda ve ekonomik düzeyinde artış beklenmektedir.

\section{Kentin Kültürel ve Arkeolojik Miras Değerleri}

Kentin Osmanlı Dönemi öncesi tarihi, yazılı belgelere ve müzelerde sergilenen arkeolojik buluntulara dayalıdır. Bu bilgi kaynaklarına göre Lapseki kenti, kuruluşundan bugüne konumlandığı coğrafyada sürekli yerleşim alanı olarak çok katmanlı bir kenttir. Antik kent bugünkü yerleşimin tam merkezindeki alçak tepe üzerinde yer almaktaydı. Tepenin en dik olan bölümü boğaza bakan batı yönüdür. Diğer kesimler hafif eğimli bir topografyaya sahiptir. Tepenin üst kotundaki teras izlerinin akropol, kuzeyindeki mezar kalıntılarının nekropol alanına ait olduğu bilinmektedir. Lampsakos'ta ilk kazı çalışmasını yapan 1893'de Celil Bey ve 1895'de Sabri Bey nekropol alanında çok sayıda mezarı kazmışlardır. Sabri Bey 1943'de yaptığı kazıda, M.S. 193'e tarihlenen en eski sikke ve M.S. 240'a tarihlenen en yeni sikke olmak üzere 684 adet Roma Dönemi sikkelerinde oluşan bir define bulunmuştur. 1960-61 yıllarında bugünkü kent merkezinin güneyinde Yenice köyü yolu üzerinde Çeşmecikler mevkiindeki Lapseki-Yenice yol çalışmalarında ve 2005 'de Çanakkale Müzesi tarafından yapılan kurtarma kazısinda bulunan lahit mezar ve M.Ö. 5-4. yüzyıla tarihlenen arkeolojik buluntular İstanbul Arkeoloji Müzesine ve Çanakkale Müzesine teslim edilmiştir. $\mathrm{Bu}$ alanın, antik kentin güney giriş kapısı yönündeki yolun kenarındaki başka (güney) nekropol alanı olduğu da düşünülmektedir (Arslan, 2007). 
Akropol alanında ortaçağa tarihlenen sur ve keramik parçaları, İstanbul Arkeoloji Müzesinde sergilenmektedir. Bizans ya da Ceneviz Döneminde inşa edilen ve Osmanlı Döneminde 15. yüzyılın ilk yarısında yıktırılan kaleden geriye, apartmanların arasında sur kalıntıları kalmıştır (Arslan, 2008; Körpe, 1998). Kentin antik dönem yapılarının önemli bölümünün toprak altında olduğu düşünülse de çoğunluğunun başka yapıların inşasında kullanıldığı görülebilmektedir. Bu nedenle, arkeolojik kazılarla bulunan lahitler ve ostothekler, mezar ve kalıntıları içerisindeki bazı eşyalar ve sikkeler de kent tarihinin temel bilgi kaynaklarıdır.

Antik Çağda kentlerin bağımsızlığını ve sosyo-ekonomik düzeyini simgeleyen sikke darbı, Troas bölgesinde M.Ö. 6. yüzyılda kendi adına ilk sikke basan kent olarak Lampsakos'a aittir. M.Ö. 500'lere kadar elektron, daha sonra altın ve gümüşten olan bu sikkelerinin basımına Roma İmparatoru Gallienus (218-268) dönemine kadar devam edilmiştir (Arslan, 2007). Lampsakos'un erken dönem sikkelerinde Pegasos, Athena, Apollon betimlemeleri yer alır. M.Ö. 4. yüzyıl sikkelerinde Zeus, Demeter ve Pers satraplarının portreleri gibi çeşitli betimlemeler bulunmaktadır. M.Ö.370 tarihli Lampsakos'un altın sikkesinin (8.35 gr.) ön yüzündeki pelerin giysili hububat ve bereket tanrıçası Demeter ve üç başaklı tahıl, sol omuz üzerinde iki başak, asma dalı ve üzüm salkımı figürleri, kentin tarıma dayalı zenginliğini, arka yüzündeki Pegasos (Kanatlı At) deniz ticaretindeki hâkimiyetinin göstergesidir (Asia Minor coins, 2011). Bu sikkedeki Pegasos figürü (Foto 1a) dünyada ilk defa adına para basılan kent olan Lapseki kentinin simgesi olarak Gazi Mustafa Kemal Atatürk Meydanındaki anı (Foto 1-b) ve 2012'de İskele Meydanına dikilen heykel (Foto 1-c) gibi çeşitli alanlarda ifade edilmektedir.

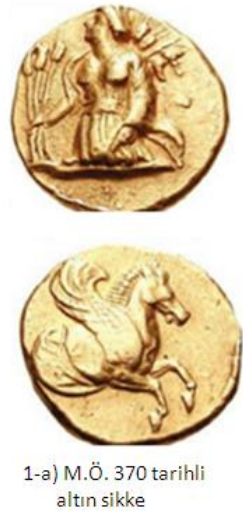

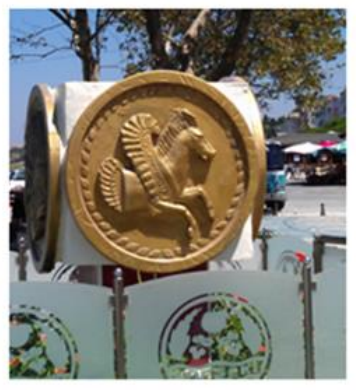

1-b) Pegasos Anitı

Gazi Mustafa Kemal Atatürk Meydanı

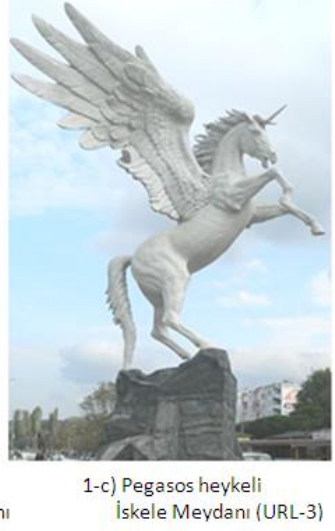

Foto 1. Antik Dönemde Sikke Figürü, Günümüzde Lapseki'nin Simgesi Pegasos (Odabaşı, 2012) 
M.Ö. 190-85 yıllarındaki Magnesia (Manisa) Savaşından sonra basılan sikkelerde bereket tanrısı Priapos'un başı ve Apollon Kitharodos betimlemeleri kullanılmıştır. Roma Çağı sikkelerin arka yüzünde ise Tanrı Priapos (Bereket) çok sık görülür. Çanakkale Müzesinde Roma devrine M.S. 3. yüzyıla tarihlenen "Stephonos bu lahdi kendisi karısı ve çocukları için yaptırdı. Eğer bir kimse bunun içine başka ceset koyarsa, şehre 2500 hazineye de 3000 denar ödeyecektir" yazısı olan, girlantlı bir lahit sergilenmektedir (Antik Dönem, 2013)

Helenli tarihçi Ksenephon'un M.Ö. 370'de yıllarına ait Anabasis (Onbinlerin Dönüşü) adlı eserine göre; Lampsakos yakınında tüm sanatların, ış1ğın, ateşin, şifanın, bilgeliğin ve kehanetin tanrısı Apollon için büyük bir tapınak inşa edilmiştir (Ksenephon, 2019). Ancak bu tapınağın izi bile kaybolmuştur.

Lapseki, Türklerin eline geçtikten sonra yeniden imar edilmesine karşın bugüne ulaşabilmiş tarihî yapı sayısı çok azdır. Arşiv ve seyyah kayıtlarına göre bunlar arasında kale, Emir Süleyman Burgazı, Özbek Vakfı'na ait imâret ve camii, Cerrah Hamza Kervansarayı, hamam, kentteki hanları ve bir namazgâh sayılabilir. Karesi Beyliği dönemine tarihlenen Gazi Süleyman Paşa Camii 1896-1897'de onarıldığı için varlığı sürdürülmektedir. Bu caminin mihrap nişi ile minare kaidesi özgün görünmektedir. Caminin doğu tarafındaki küçük hamam kalıntısı konak hamamı tipinde olup, 19. yüzyıl sonu ile 20. yüzyıl başlarına tarihlenebilir. 18. yüzyıl taşra örneklerine benzeyen Şerîfe Ayşe Hatun Çeşmesi (1768) ve kültür mirası tescili olmayan birçok çeşme kentte yer almaktadır (Uysal, 2013). Tarihi merkezdeki Han Sokak ve Hamam Sokak, Evliya Çelebi'nin anlattı̆̆ han ve hamamın var olduğu yeri açıklamaktadır.

\section{Kuzey Nekropol (Dalyan Mevkii, Üçüncü Derece Arkeolojik Sit) Alanı}

1996' da Lapseki-Dalyan mevkiinde bir bina inşaatının temel hafriyatında taş mezarlar ve bazı altın eşyaların bulunmasıyla, Çanakkale Müze Müdürlüğü bu alanda Anitlar ve Müzeler Genel Müdürlüğü'nün 19.09.1996 gün ve 7539 sayılı kazı ruhsatı ile kurtarma kazısı yapmıştır. Bu kazıda taş mezar ve iskelet kalıntıları, parçalanmış iki lahit ve içerisinde yanmış kafatası parçaları, bronz bir ayna, Nike kabartmalı aplik parçası, arı kabartmalı bir yüzük ve işlenmiş kemik parçaları olan bir ostothek, üç adet altın çelenk, iki adet altın diadem, iki gümüş sikke, bir altın yüzük, boncuk, altın ve keramik parçaları bulunmuştur. Bu sikkeler M.Ö. 500'lere, mezarlar ve diğer buluntular M.Ö. 4. yüzyıl ortalarına tarihlenmiştir. Çanakkale Müzesinde sergilenen altın 
buluntular, kentin bu dönemde altın üretim merkezi olduğunun kanıtlarıdır (Körpe, 1998). M.Ö. 5. yüzyıla tarihlenen mezar stelleri Atina Müzesi ve İstanbul Arkeoloji Müzesinde sergilenmektedir (Arslan, 2007).

1996'da yapılan bu arkeolojik kazı sonuçlarına göre antik Lampsakos kentinin kuzey nekropol alanının yeri ve üçüncü derece arkeolojik sit alanı sınırları belirlenmiştir (Şekil 2).

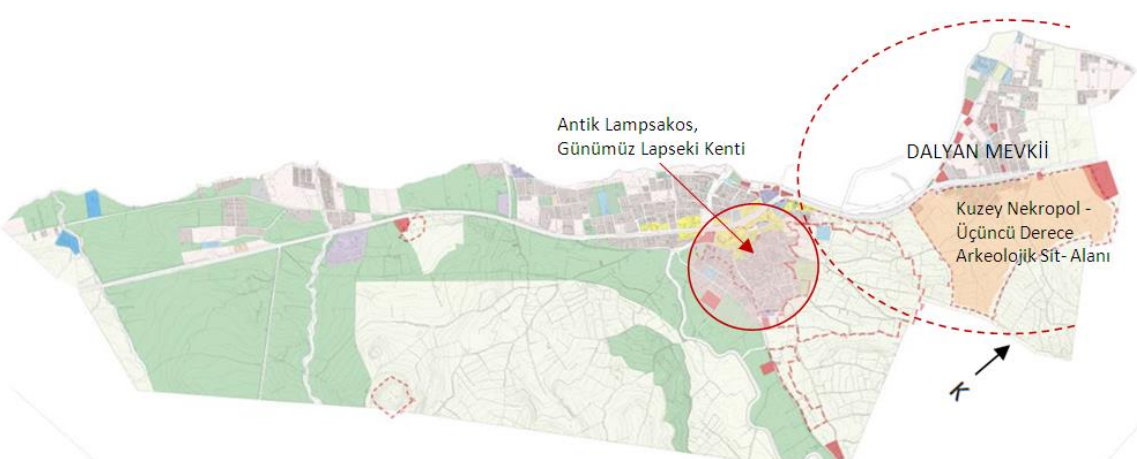

Şekil 2. Lampsakos-Kuzey Nekropol Alanının Günümüzdeki Kentsel Konumu

(KAIIP, 2019)

\section{Lapseki (Lampsakos) Kenti Kuzey Nekropol (Üçüncü Derece Arkeolojik Sit) Alanı Koruma Planlaması}

05.06.2015 tarihinde onaylanan Balıkesir - Çanakkale Planlama Bölgesi 1/100.000 ölçekli Çevre Düzeni Planına- ÇDP (pafta H17) göre; Lampsakos Antik Kenti-Kuzey Nekropol Alanının yer aldığı bugünkü Lapseki Merkez Dalyan Mevkii, kuzeyindeki Çardak Beldesine kadar gelişme konut alanı olarak belirlenmiştir (Şekil 3.a). Bu planla Lapseki merkezde tarım ve sanayi sektörleriyle birlikte kırsala yönelik eğitim ve sağlık gibi kamu hizmetleri, bölgesel gelişim için ulaşım ve lojistik hizmetlerinin geliştirilmesi öngörülmektedir. Bu faaliyetlerle 2040 yılı nüfusu 24.580 kişi olarak planlanmıştır (Çevre ve Şehircilik Bakanlığı, 2015). Ancak, \% 90'u yapılaşmış planlı alanda (2012 nüfusu 10.863 kişi iken) 2019 nüfusu 13.818 kişiye ulaşmıştır. Bu hızlı nüfus artışı nedeniyle ivedilikle yaklaşık 10.000 kişilik nüfus için konut alanı gereksinimi söz konusudur. Sit alanı ilanıyla mer'i imar planlarının (Şekil 3.b) iptal edilmesiyle, doğal eşikler (orman, ağaçlık alan, yüksek eğim, vb.) nedeniyle üçüncü derece arkeolojik sit alanının yeniden planlanması zorunlu olmuştur (Şekil 3.c). Lampsakos Antik Kenti-Kuzey Nekropol Alanı için önerilen KAİP ile 85 hektar büyüklügündeki alanda, sosyal donatıları ve 
diğer kullanımları ayrıldıktan sonra konut için kullanacak 30 hektar alanda projeksiyon nüfusu 8.000 kişi kabul edildiğinde yoğunluk (brüt 95 kişi/ha, net 250 kişi/ha) ÇDP hedeflerine ve mevcut kent dokusuna uygun görünmektedir (KAİ, 2019).

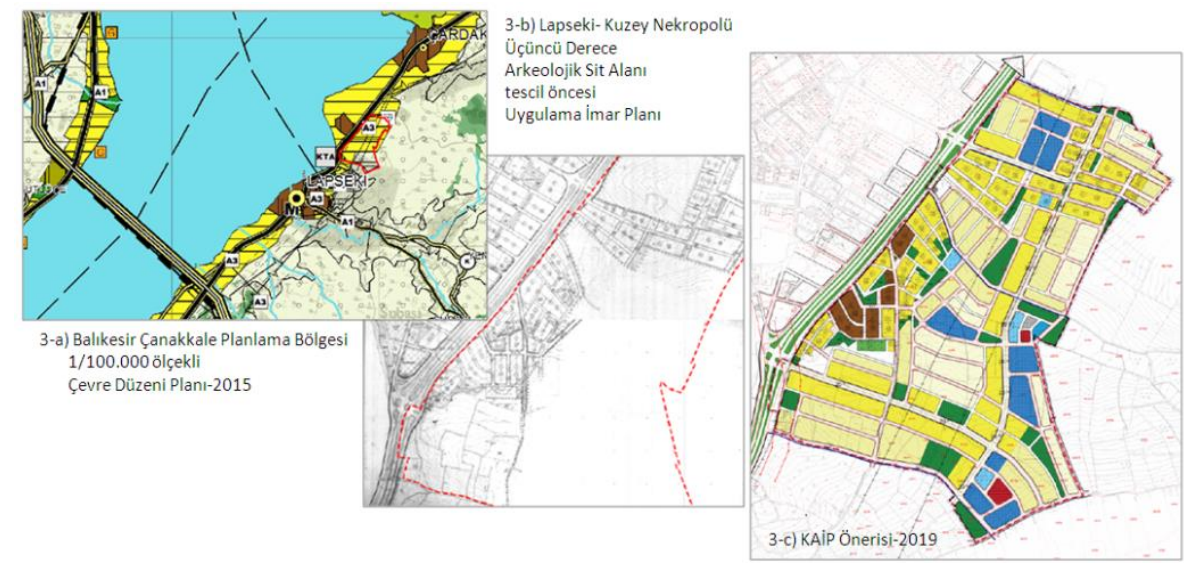

Şekil 3. Lampsakos-Kuzey Nekropol Alanında Mevcut ve Öneri Planlar (KAİP, 2019)

Kentin morfolojisi ve güneyde sinırdaş olduğu Çanakkale 1915 Köprüsü yönünde gelişmenin engellenmesi ve diğer kısıtlar (kıyı, koruma, tarım alanı, vb.) dikkate alındığında, önerilen KAİP ret edildiğinde kentte yoğunluk 2.5 kat artacak, sosyal ve teknik alt yapı yetersizliği yaşanacak ve çevre ve kültür değerlerini yadsıyan kaçak yapılaşmayla sağlıksız kentsel gelişme kaçınılmaz olacaktır. Kurum görüşleri beklenen öneri KAIIP planı, kentin bu gelişme gereksinimi ve arkeolojik miras değerlerini koruma potansiyeli, sürdürülebilirlik bağlamıyla aşağıda incelenmektedir.

\section{KAIP Amaç, Hedefleri ve Stratejileri}

Onay aşamasındaki KAİP amacl; planlama alanının, doğal, çevresel, kültürel ve arkeolojik değerlerini sürdürülebilirlik ilkesiyle koruyarak Bölgenin, Türkiye'nin ve Dünyanın bilgi ve görüşüne açllması, rasyonel kullanımına ve/veya çağdaş kente ve kimliğine katılımına ilişkin uygulanabilir, ulaşılabilir planların, yönetim ve uygulama rehberinin hazırlanması ve böylece coğrafi bağı olan kent ve ülke ekonomisine değer kazandırması, sosyal ve kültürel yaşama eklemlenmesidir. Bu amaçla plan elde etmede farklı boyut ve sürelere (kısa/orta/uzun erimli) ilişkin hedefler belirlenmiştir. 
Çeoresel değerleri korumaya-yaşatmaya yönelik hedefler;

- Doğal, çevresel, sosyal ve kültürel değerlere odaklı sürdürülebilir yerleşim alanı oluşturmanın ilke ve hedeflerini esas kabul etmek, Fiziki mekâna yönelik hedefler;

- Alanı tarihi kültürel peyzaj değerlerine uygun planlamak,

- Her türlü yapılaşmada yerellik, bütüncüllük, doğallık ve çevre duyarlılık kriterlerini sağlamak,

Fiziki mekâna yönelik stratejiler;

- Planlama alanının erişilebilirliği, önerilen kara ve deniz ulaşım bağlantıları ile güçlendirilecektir.

- Yapılaşmada alanın morfolojik yapısı (eğim, yükselti kodları vb.) ve yerel mimari temel alınacaktır.

- Çanakkale ilinin birinci derece deprem kuşağında yer alması nedeniyle ilgili kanun ve yönetmeliklere, deprem duyarlı planlama ve tasarım ilkelerine uyulacaktır.

- Kentsel teknik ve sosyal altyapı olanakları geliştirilecektir.

- Mekânsal planlamada, arkeolojik miras alanı farklı görsel araçlarla (meydan tasarımları, ışık gösterileri, heykel, sokak ve bina adları vb.) tanımlanacaktır.

- Planlama alanının yerinde korunamamıs arkeolojik ve mitolojik miras değerleri, tarihi birikimi simgeler aracılığıyla tanıtılacak, yaşatılacaktır.

Sosyo-kültürel hedefler;

- Planlama alanında yaşanabilirliği ve/veya yaşam memnuniyetini sağlamak,

Sosyo-kültürel hedeflere yönelik stratejiler;

- Doğal ve kültürel mirası dolayısıyla arkeolojik değerleri korumakollama, yerel sahiplilik ve farkındalık bilincini geliştirilecek ve böylece aidiyeti pekiştirilecek,

- Kentin tarihi birikimine dayalı kültür turizmi ile gelişecek kültürel iletişim ve dostluk ortamları yaratılacak,

- Sosyal sermaye sürdürülebilir kalkınma programlarıyla miras değerlerinin sürdürülebilirliği ile ekonomik gelişmeye yönlendirilecek,

- Kentin tarihi geçmişi ve özellikle nekropol alanıyla ilişkili kimliğinin tanınırlı̆̆ını sağlamak amacıyla sosyal aktiviteleri (festival, panel vb.) yönlendirilecek, paylaş katılım ortamlarını (yazılı ve görsel basın, panel, film gösterileri vb.) hazırlanacak, sorumluluk projeleri (fotoğ- 
raf, kompozisyon, hikaye-roman, belgesel film yarışmaları vb.) desteklenecektir.

\section{Ekonomik hedefler;}

- Sürdürülebilir kültür turizmi ile ekonomik katma değer elde etmek ve yayginlaştırmak,

Ekonomik hedeflere yönelik stratejiler;

- Yerel kültür ve arkeolojik miras değerlerinin tanınırlığı ve çağdaş kente entegrasyonu ile katma değer oluşturulacak ve bu konudaki uygulamaları geliştirilecek,

- Turizm potansiyelleri (deniz, boğaz, orman, ticaret vb.) değerlendirilecek ve sürdürülebilir turizmi desteklenecek,

- Ulusal ve uluslararası tur güzergâhlarına ve kültürel rotalara eklemlenilecek,

- Kentin turistik imajı tarihi ve arkeolojik değerleriyle güçlendirilecek,

- Büyüyen dünya turizminde planlama alanının stratejik öneminin ve tarihi imajınn (felsefe merkezi, din merkezi gibi) sağlayacağı avantajlar değerlendirilecek,

- Arkeolojik kalıtı simgeleyen objelerin üretim ve pazarlama ortamları hazırlanacak ve böylece istihdam yaratılacaktır.

Yönetsel hedefler;

- Kültürel mirasın özellikle arkeolojik değerlerin korunmasında tarafları uzlaştırıcı, katılımcı planlama anlayışını geliştirmek ve sürekli kilmaktır.

Yönetsel hedeflere yönelik stratejiler;

- Planlama alanının yaşanabilirliği ve sürdürülebilirliğini sağlamada paydaş katılımı ve ortaklıkları (yerel/merkezi yönetim, eğitim kurumları, sivil toplum örgütleri, dernekler vb.) etkin kılınacak,

- Turizm ve miras yönetiminde ulusal ve uluslararası destek ve finansman olanakları ortak akıl ve katılımla değerlendirilecektir.

\section{KAIPP Planlama Yaklaşımı, İlkeleri ve Araçları}

KAIIP yaklaşımı; planlama alanının özelliklerine bağlı olarak belirlenmiştir. Dolayısıyla alanın üçüncü derece arkeolojik sit alanı statüsü dikkate alınarak, çevre duyarlı planlama, sürdürülebilir kentsel yerleşim ve koruma planlaması birbirini besleyen planlama yaklaşımlarıdır. Bu yaklaşımların arakesitinde; insanın yaşamının bugünü ve geleceğini önemseyerek, planlama alanının yenilenemez doğal ve kültürel kaynaklarının korunması ve sürekliliğinin sağlanması temel planlama ilkesidir. Bu kaynakların nitelik 
ve nicelik olarak sabit kalmasını savunan ve doğal sermaye ile insan sermayesi (ekonomik refah, bilgi temeli, vb.) arasındaki ilişkiyi yadsıyan saklamaCı ve kullanımı engelleyici koruma yaklaşımına karşın, KAİP ile bu değerler üzerinde koruma-kullanma dengesinin sağlanması ve geliştirilmesi benimsenmektedir. Uluslararasında sürdürülebilir gelişmenin -gelişmiş ülkelerden farklı olarak- yer'e özel tanımlanması ve yer'e özgü uyumlandırılması planlamanın paradigmasıdır (Sustainable Development, 2020). Bu paradigmaya referansla miras değerlerinin korunması, rasyonel ve yenilikçi yöntemlerle kullanılması sürdürülebilirliğin çevresel, sosyal ve ekonomik boyutlarına katkı sağlayan etkin bir araçtır (UNESCO, 2017; United Nations, 2012). Güncel bu gelişmelere koşut olarak arkeolojik mirasın sürdürülebilirliğine odaklı KAİP ilkeleri;

- Kültürel ve doğal değerlerin koruma-kullanma dengesi çerçevesinde sürdürülebilirliğini sağlamaya yönelik gerçekçi ve alana özgü koşulları yeniden yapılandırmak ve sürdürülebilir kalkınmada etkin kılmak,

- Arkeolojik mirasın çağdaş kente entegrasyonunu sağlamak,

- Korumayı ekonomik kılacak olanakları faydacı kılmak, yerel dinamiklerle destelemek ve böylece sosyal kapitali de güvence altına almak,

- Çanakkale 1915 Köprüsü ile Lapseki kentinin üstleneceği yeni rolleri hayata geçirmek, bütünlük ilkesi ile planlama alanı ve yakın çevresinde hatta etki alanı Çanakkale İl genelinde, sürdürülebilir kalkınmayı, ekonomik kararlarla birlikte yenilenemez değerlerin değerlendirilmesine dayalı fiziksel planlarla desteklemek ve böylece ekonomik ve sosyal olguları bütünleştirmek,

- Bölgeye ve yerel değerlere uygun kentsel tasarım ve yapı tasarımlarının gerçekleştirilmesinde yönlendirici plan kararlarını oluşturmak olarak tanımlanmaktadır.

- KAİP bu ilkelerle, sürdürülebilirliğin dolayısıyla KAİP hedeflerine aşağıda -kısaca- açıklanan boyutlarda erişilebileceği planlanmıştır.

- Ekonomik: iskân ve istihdam gibi temel gereksinimlerin karşılanması, tanınırlı̆ın ve farkındalığın sağlanmasıyla kültürel turizmin geliştirilmesi ve elde edilecek katma değerin taraflarca paylaşılması,

- Çevresel: doğal ve kültürel kaynakların sürdürülebilirliğe odaklı biçimde rasyonel kullanımı,

- Sosyal: farklı grupların ve/veya komünitelerin geleceklerini oluşturmada güçlendirilmesi, yerel değerler ve/veya motifler aracllığıyla aidiyetin ve kimliğin pekiştirilmesi, 
- Kültürel: barış, huzur, dostluk ve güven ortamının sağlanmasında kent planlamanın etkinleştirilmesi, kültürel sürekliliğin gerçekleştirmede arkeolojik motiflerden yararlanılması.

\section{Çanakkale 1915 Köprüsünün Lapseki Kentine Ve Üçüncü Derece Arkeolojik Sit Alanına Etkileri}

18 Mart 2017 tarihinde temeli atılan ve 2022'de hizmete açılması planlanan Çanakkale 1915 Köprüsü (yan açıklık 770 m., toplam yükseklik 318 m.) Gelibolu'yu (Avrupa'yı) Lapseki'ye (Asya'ya) bağlayan 2023 m. uzunluğu ile dünyanın en uzun asma köprüsü olacaktır (Apaydın ve Baş, 2018). Türkiye'nin I. Dünya Savaşı zaferinin tarihi ile adlandırılan bu köprü, bellek ve farkındalık yaratarak ülkenin, Çanakkale'nin ve Lapseki'nin tanınırlı̆̆ını artıracaktır. Bu köprü ile sanayileşmiş Kuzey Marmara'dan görece daha az sanayileşmiş Güney Marmara'ya ring bağlantısı sağlanarak Marmara Bölgesi'ndeki kentlere ulaşım kolaylığıyla birlikte Türkiye'nin Avrupa ve Akdeniz ile lojistik bağlantısı güçlendirilecektir. Ekonomik açıdan turizm ve ticari mal akışı ve bu faaliyetleri destekleyecek yan sektörler (konaklama, yeme-içme, ulaşım vb.) gelişecektir. Ayrıca, Bozcaada-Gelibolu geçişinin ve Çanakkale-Malkara otobanının hizmete açılmasıyla ve ÇDP ile öngörülen yeni işlev alanlarıyla (depolama, soğutma, konaklama, sağlık vb.) yatırımlar dolayısıyla istihdam olanakları da artacaktır (Tanoğlu, vd. 2019). Böylece kentin göç alması ve/veya nüfus artışı dolayısıyla konut talebi çok yakın gelecekte gündeme gelecektir. Bu gelişmede yapılaşmasını tamamlamış görülen kent merkezine nüfus yükleyerek yapı yoğunluğunu artırmak için yıkıp-yeni yapı yapma maliyetleri ekonomik olmayacağı ve arsa spekülasyonunu körükleyeceği (imarlı konut arsası m²'si 2014'de 600-800 TL., 2017'de 1850-2100 TL. iken 2019'da 3.500-4000 TL.'ye ulaşmıştır) gibi aşılamayacak birçok kentsel yetersizliklere (belediye hizmetleri, sosyal donatı, teknik alt yapı, güvenlik gibi) neden olacaktır (KAİP, 2019).

Çanakkale 1915 Köprüsünün ivme kazandıracağı ekonomik ve sosyal gelişmede, koruma mevzuatının hükümlerine ve güncel koruma yaklaşımlarına uygun olarak üçüncü derece arkeolojik alanların planlanması ve böylece yapılaşmaya açlması yani kent için yaşamsal zorunluluğa dönüşen gelişme ve/veya konut talebini karşılama, arkeolojik değerlerin sürdürülebilirliği açısından fırsata dönüştürülebilir. 


\section{Sonuç ve Değerlendirme}

Lapseki (Lampsakos) kenti Çanakkale Boğazında Ege ve Karadeniz havzasinı birbirine bağlayan konumuyla koloni olarak kuruluşundan bugüne doğu (Asya) -batı (Avrupa) arasında geçiş alanı olarak jeo-stratejik önemini sürdürmektedir. Kentin tarihsel süreçteki ekonomik, sosyal ve kültürel gelişmişlik düzeyi Çanakkale 1915 Köprüsünün açılmasıyla giderek artacaktır. $\mathrm{Bu}$ ortamda kentin doğal ve yasal eşiklerine ve ÇDP hükümlerine göre Lampsakos Kentinde Kuzey Nekropol Alanı, gelişme konut alanıdır. Bu nedenle koruma mevzuatına göre; koruma, kullanma kararları doğrultusunda yeni düzenlemelere izin verilebilecek üçüncü derece arkeolojik sit alanı olarak yerleşime açılabilen nekropol alanında arkeolojik değerleri koruma ve sürdürülebilirliği sağlamak amacıyla KAİP planı hazırlanmıştır.

Günümüzde Çardak Yolu üzerinde yapılaşmanın tamamlandığı planlama alanında (Şekil 2, Şekil 3-b) toprak üzerinde ve farklı tarihlerde yapılan arkeolojik kazılarla bulunan eserlerin müzelere taşınmasıyla herhangi bir arkeolojik kalıt bulunmamaktadır. Ancak KAİP uygulama sürecinde sondaj kazısı zorunluluğu, arkeolojik mirasa ulaşmada fırsat olabilir. Böylece çağdaş kentin konut gereksinimi karşılanırken, kentliye tarihiyle birlikte yaşama ayrıcalığı kazandırılıp, arkeolojik mirasın çağdaş kente entegrasyonu sağlanabilir. Bu konuda İtalya'da Verona kenti bilinen örneklerden biridir. Ayrıca Antakya kent merkezinde, üçüncü derece arkeolojik sit alanındaki otel inşaatında $200 \mathrm{~m}^{2}$ alanda çeşitli taban mozaikleri ve $850 \mathrm{~m}^{2}$ büyüklüğünde dünyanın tek parça en büyük mozaiği bulunarak, birinci derece arkeolojik sit alanına dönüştürülen parselin zemininde müze, zemin üstü 4 katta 250 yataklı otel inşaatı 2020'de tamamlanmıştır. Sayısız koruma ve mimari tasarım ödülü alan Antakya Müze Otel, arkeolojik değerlerin yerinde sergilenmesi zorunluluğuyla süre giden koruma ile ekonomik gelişme arasındaki gerilimi kaldırmış, kente ulusal ve uluslararasında saygınlık kazandırmış, turizmin gelişmesini sağlamıştır. Bu yapı, Türkiye'de koruma planlamasının ya da mevzuatın engel olmadığını açıklayan ve arkeolojik mirasın sürdürülebilirliği açısından ÜMITVAR PROJE olan en iyi örnektir (Türk ve Gültekin, 2019).

KAİP uygulamasında herhangi bir arkeolojik kalita rastlanmaması durumunda bu nekropol alanı ve arkeolojik sembolleri, kentin simgesi olarak kullanılarak, kentlilerin kendilerine ait değerleri nekropol üzerinden çağrıştırarak, kentlilerin kaynaşması, kentin belleği, kimliği ve aidiyet duygusu geliştirilebilir. Antik Lampsakos kentinin dünya tarihinde ilk sikke basılan 
kent olması, tüm dünyanın tanıdığı mitolojik figür Pegasos'un, nekropol alanında bulunan sikkelerde ilk kez kullanılmış olması, bu kente ait bu figürün kentin simgesi olarak yaygınlaştırılmasının haklı gerekçesidir. Küreselleşmeyle kentsel rekabette markalaşmanın aracı olarak yaygınlaştırılan bu tür kent simgeleri (Liverpool Kentinin Liver Kuşları -Liver Birds gibi)

${ }^{13}$ birçok kente ayrıcalık ve tanınırlık kazandırıp, kentin sürdürülebilir kültür turizminde önemli destinasyon olmasını sağlamaktadır. Ayrıca, Pegasos figürünün marka olarak bu kente tescili yapılarak, Lapseki kentine ait olduğunu belirtmek koşuluyla ticari firmalara kullanım hakkı verilerek ekonomik katma değer oluşturulabilir. Günümüzde bir havayolu firmasının kullandığı bu figürle kentin ulusal ve uluslararası kara ve deniz ulaş1mında da görünür olması kültür turizmi için çekicilik yaratsa da marka tescilinin bu kente yapılmasıyla ekonomik getiri artırılabilir. Aynı amaçla farklı araçlar geliştirilebilir, Çanakkale 1915 Köprüsünün simgesi Pegasos olabilir.

Sonuç olarak; Lapseki (Antik Lampsakos) kenti, Kuzey Nekropol (Üçüncü Derece Arkeolojik Sit) Alanının KAIIP ile arkeolojik miras alanlarının atıl yada kayıp alanlar (lost-space) olarak bırakılması değil çağdaş kente entegre edilerek sürdürülebilir kalkınmada firsatlar yaratabileceği anlaşılmaktadır. Ayrıca, üçüncü derece arkeolojik sit alanlarını KAİP ile yapılaşmaya açma Türkiye'de koruma mevzuatına aykırı olmadığı gibi uluslararasında öngörülen kültürel mirasın sürdürülebilir ekonomik kalkınmayı desteklemesine, koruma planları ve miras yönetimiyle rehberlik edilmesi ve en etkin uygulama aracının sürdürülebilir kültür turizm olması yönündeki yenilikçi koruma politikalarına da (UNESCO-WHC, 2015) uygundur.

\footnotetext{
${ }^{13}$ Kraliyet Binasının iki kulesi üzerindeki Karabatak kuşuna benzeyen dişisi Bella ve erkeği Bertie adlı kuşların heykelcikleri kenti simgelemektedir. Bella, gemilerin limana güvenli ulaşımı için denize, Bertie kentlileri korumak için kente doğru bakmaktadır. Söylenceye göre; 1207'de Liverpool'un kent olarak tanınması için gerekli olan mühür için kuşlara bu misyon yüklenmiştir. 1797'de bu sembol kentin arması olarak tescil edilmiştir (De Figueiredo, 2003; Russell, 2007).
} 


\title{
Extended Abstract
}

\section{Protecting Third Degree Archaeological Sites: Lampsakos Northern Necropolis Area}

\author{
$*$ \\ Erman Aksoy \\ ORCID: 0000-0001-7660-1054
}

As of the 21st century, with new (updated) approaches to the sustainability of cultural heritage, it is envisaged that the archaeological heritage is preserved in situ together with its tangible and intangible (physical and spiritual) components, and its integration into the modern city and its utilization in sustainable development. Examples of good practice in Turkey with this approach, thus integrating sustainability of current protection legislation in the contemporary urban archaeological sites shows that the obstacles in providing economic value added.

Archaeological heritage, as a component of the soul of the place, conveys the social, cultural and economic accumulations of the city in which it is located, settlement and architectural traditions, the meanings it attributes to the place, and gives the urban dignity the privilege of understanding its past, its roots and living with its history, gaining prestige and recognition. Archaeological heritage can be socially, economically, functionally, aesthetically, visually and physically integrated with the city according to its structural condition and potential, and thus, it can be transformed into values that reinforce memory, identity and belonging and / or enrich the spirit of the place. In opening to the views and knowledge of all people where the archaeological heritage is located; some figures that were symbols of the city in the past may be effective as well as the visual and semantic integrity of the archaeological works. Especially in cases where material-tangible (physical) cultural values cannot be preserved, as is frequently encountered in tertiary archaeological sites, the sustainability of the archaeological heritage can be achieved by means of spiritual-intangible values or symbols. For this reason, in this article, in order to illustrate the continuity of urban landmarks belonging to tertiary archaeological sites, the Northern Necropolis of the 
Ancient City of Lampsakos in this registered status is examined. In the analysis of this plan, the construction pressure that denies the archaeological heritage, as the 1915 Çanakkale Bridge accelerated the rapid development in the planning field, was also determinant.

On the Anatolian coast of the Dardanelles (Hellespontos), BC. Lampsakos (Lapseki), known to exist as a small trade pier (embrio) in $3000 \mathrm{BC}$, was founded in BC. It has maintained its importance in war and peace since the day it was founded simultaneously with the Miletus colonies in the early 7th century. Due to its geo-strategic importance connected to the transition point between east and west, the city has maintained its existence as a science and culture center with its strong economy and with the trade of agricultural products obtained from the fertile plains in its hinterland. The ancient city was located at the narrowest point of the Dardanelles Strait, on the hill in the center of today's settlement, in the small bay on the opposite shore of Gallipoli (Gallipolis). It is known that the traces of the terrace on the upper elevation of this hill belong to the acropolis, the remains of the tomb to the north necropolis area and the sarcophagus tomb and remains in the southern necropolis area in the present Yenice road Çeşmecikler area to the south. The northern necropolis area was registered as a third degree Archaeological Site in 1997, and its border was finalized in 2014 without changing the degree of protection.

In the Balıkesir - Çanakkale Planning Area - Environmental Plan (ÇDP) dated 2015, Lapseki Merkez Dalyan Region, where the Northern Necropolis Area is located, was determined as a development housing area up to Çardak Town in the north. Although the population of the city in 2040 was planned as 24,580 people with this plan, 2019 population reached 13,818 people in the planned area, $90 \%$ of which was built. Due to this rapid population growth, housing space is required for a population of approximately 10,000 people. The cancellation of the land development plans with the site announcement area and the insufficient area of settlement due to natural thresholds necessitated the re-planning of the third degree archaeological site. With the KAIP proposed for this protected area, the planned population size (8,000 people) and density (gross 95 people / hectare, net 250 people / hectare) in an area of 85 hectares and 30 hectares of dwellings seem to be in line with the ÇDP targets and the existing urban texture. When KAIIP is rejected, the density in the city will increase 2.5 times, and lack of infrastructure, economic and social losses will be inevitable in the process of illegal construction, demolition and reconstruction that negate environmental and 
cultural values. Therefore, according to this upper scale plan and conservation legislation; the necropolis area, which is a third degree archaeological site, can be opened to construction.

This settlement decision is justified by the absence of any archaeological heritage in the area today. However, it is known that the artifacts found in the planning area in 1893, 1895, 1960-61 and 1996 and in the archaeological excavations in the southern necropolis in 2005 were exhibited in Istanbul Archeology Museum, Çanakkale Museum and Athens Museum. The sarcophagi and ostotheks, tombs and their remainings, some items and coins found in archaeological excavations are the main sources of information in the history of the city. According to the KAIP of this mythological figure in the coins found in the northern necropolis area of the ancient city, that is, in the third degree site area; the registration and dissemination of the city as a symbol will create an opportunity for the sustainability of the archaeological and cultural heritage and for obtaining economic value in sustainable development. As a result, it can be said that these plans are tools that accelerate the development rather than preventing the development through the KAIP plan examined.

\section{Kaynakça/References}

Akurgal, E. (2000). Ege: Batı uygarlı̆̆ının doğduğu yer. İzmir Büyükşehir Belediyesi, İzmir Yayincilik, 14.

Al, M. (2011). Kentte Bellek Yıkımı ve Kimlik İnşası-Palimpsest: Ankara Atatürk Bulvarı Bağlaminda Bir İnceleme. İdealkent, 2(4), 22-36.

Antik Dönem. (2013, 01 Kasım). Lapseki antik Kenti-Çanakkale Lapseki. https://antikdonem.tumblr.com/post/88288051221/lapseki-antik-kenti\%C3\%A7anakkale-lapseki adresiden erişilmiştir.

Apaydın, M.N. ve Baş, S. (2018). Long-Span Orthotropic Steel Deck Bridges of Turkey. $9^{\text {th }}$ International Symposium on Steel Bridges. IOP Publishing IOP Conference Series, $419,1-9$.

Arslan, A. (2008). Antik Çağda Lampsakos/Lapseki. Lapseki Sempozyumu'07, 167-174.

Arslan, N. (2008). 2007 Yllı Lampsakos/Lapseki, Abydos ve Çan Yüzey Araştrrması. 26. Araştırma Sonuçları Toplantısı, c.1.

Asia Minor Coins. (2011, 24 Kasim). Lampsakos (BC 394-330) AV Stater - Aktaion, https://www.asiaminorcoins.com/gallery/thumbnails.php?album=104 adresinden erişilmiştir.

Bakır, T. (2003). Daskyleion (Tyaiy Drayahya) Hellespontine Phrygia Bölgesi Akhaemenid Satraplığı. Anadolu / Anatolia, 25, 1-26. 
Buruldağ, E. (2017). Lampsakos'ta kurulan bir Roma Kolonisi: C.G.I.L. Anadolu, 43: 7590.

Carriker, A.J. (2003). The library of Eusebius of Caesarea. Leiden, Boston. Singapore: Brill Academic Pub., 128.

Corfield, M. (2014). Archaeological Sites: Conservation and Management. Journal of the Institute of Conservation, 37(2), 197-207.

Cuinet, V. (1894). La Turquie D'Asie, Geographie Administrative, 758-762.

Çaylak Türker A. (2010). Lampsacus In Byzantine Period, Bizans ve Çevre Kültürler. M. Doğan, M. Kadiroğlu (Ed.). Prof. Dr. Yıldız Ötüken'e Armă̆an içinde (s.259-367). Yapı ve Kredi Yayınları.

Çevre ve Şehircilik Bakanlığı (2015, 05 Haziran). Balıkesir Çanakkale Çevre Düzeni Plani.

https://webdosya.csb.gov.tr/db/mpgm/editordosya/file/CDP_100000/balikesir_can akkle/H17_PLAN_05062015.jpg adresinden erişilmiştir.

De Figueiredo, P. (2003). Symbols of Empire: the Buildings of the Liverpool Waterfront. Architectural History, 46:229-254.

Doğu, T. ve Deligöz, M.V. (2017). Hafıza kutusu: Bir Kentsel Kolektif Bellek Deneyi (mi). Megaron, 12(4), 545-552.

Dukas, M. (2008). Tarih: Anadolu ve Rumeli (1326-1462). B. Umar (Çev.). Arkeoloji ve Sanat Yayınları içinde(s.78).

Evliya Çelebi (2001). Dağlı, S.4. A. Kahraman, İ. Sezgin (Yay. Haz.) Seyahatnâme içinde (s.154-155), Cilt.5 (12. Bask1) İstanbul: Yapı Kredi Yayın.

Frich, P. (1978). Die Inschriften von Lampsakos, 11-19. (ISBN 3-7749-1443-5).

Grant, R. M. (2006). Eusebius as Church Historian (2nd Edition), Wipf and Stock Publishers, 164-170.

Halaçoğlu, H. (1995). XIV - XVII. Yüzyıllarda Osmanlılarda Devlet teşkilâtı ve sosyal yapı. TTK Yayın, 45.

Hawkins, J.D. (2018). Luvilere karşı Hititler. Luvi Uygarlığı: Anadolu ve Ege arasında kimlik, kültür, dil ve din, Luvi Kimlikleri, Cilt-I, (Çev. K.Eresen) Kalkedeon Yayınları, 34-39. https://whc.unesco.org/document/139146 adresinden erişilmiştir.

ICOMOS-Brasil (2008). Declaración De Foz Do Iguaçu,.https://www.icomos.org/centre_documentation/declaration-igua\%C3\%A7uspa.pdf adresinden erişilmiştir.

İnalcık, H. (2005). Batı Anadolu'da yükselen denizci gazi beylikleri, Bizanslılar ve Haçlılar. Uluslararası Batı Anadolu Beylikleri Sempozyumu Bildiriler Kitabı, 18-20 Ekim 2004, Balıkesir Üniversitesi, 38-46.

KAIIP (2019). Lampsakos (Lapseki) Kenti, Kuzey Nekropol Alanı (Üçüncü Derece Arkeolojik Sit Alanı) Plan Önerisi Teknik Raporu, Sezgek Planlama.

Keçiş, M. ve Güneş, C. (2018). Bizans'ın Anadolu'daki yeni düzeni: Thema Sistemi'nin ortaya çıkışı ve problemler. Sosyal ve Beşeri Bilimler Araştırmaları Dergisi, 19(43), 95107. 
Korkmaz, Ş. (2005). Tanzimat Sonrası Çanakkale'nin idari ve nüfus yapısı. Çanakkale Araştırmaları Yılliğ̆ı, 3, 110-114.

Körpe, R. (1998). 1996 Lapseki kurtarma kazısı. VIII. Müze Kurtarma Kazıları Semineri, T.C. Kültür Bakanlığı Yayın, (ISBN:975-17-1875-9), 171-194.

Körpe, R. (2008). Troas Bölgesi antik kentleri. M. Demir (Ed.). Çanakkale Tarihi içinde 385, C.I. Değişim Yayınları.

Körpe, R. (2011). Antik çağlarda Çanakkale bölgesinde tarım. U. Gözel (Ed.). Çanakkale Tarım Sempozyumu, Dünü, Bugünü, Geleceği, Bildiriler Kitabı içinde 113-129 (ISBN:978-605-4222-14-8).

Körpe, R., ve Treister M. (2002). Rescue Excavations in the Necropolis of Lampsacus, 1996. Studia Trocia-Band 12 , Verlag Philipp Von Zabern, 429-450.

Köse, M. (2010). 1927 Nüfus sayımı ve sonuçlarının değerlendirilmesi. Yayımlanmamış Y. Lisans Tezi. Afyon Kocatepe Üniversitesi Sosyal Bilimler Enstitüsü.

Ksenophon (2019). Anabasis-on binler'in dönüşü. A. Çokona (Çev.) (5. Baskı), Türkiye İş Bankası Kültür Yayınları, 9-11.

Mosshammer, A. A (1979). The chronicle of Eusebius and Greek Chronographic Tradition, Bucknell University Press, 36-43.

Mouton, A., Rutherford, I., ve Yakuboviç, I. (2018). Luvi Uygarlığı: Anadolu ve Ege arasında kimlik, kültür, dil ve din. K. Eresen (Çev.) Luvi Kimlikleri içinde 8. Cilt- I, Kalkedeon Yayınları.

Nemutlu, F. E. (2019). Lapseki (Lampsakos) Antik Kentlerinin Kırsal Turizm Açısından İrdelenmesi. International Rural Tourism and Development Journal, 3(2), 52-56.

Odabaşı, Ş. (2012). Lapseki ve Pegasus. https://www.canakkaleicinde.com/lapseki-vepegasus/ adresinden erişilmiştir.

Oğuz, M. K. (2013). Temettuat defterlerine göre Lapseki Kazası'nın sosyo-ekonomik yapısı (1844- 1845). Yayımlanmamış Y. Lisans Tezi, Çanakkale Onsekiz Mart Üniversitesi, Eğitim Bilimleri Enst., 36.

Oğuz, M. K. ve Korkmaz, Ş. (2018). Lapseki Kazası'nın sosyal ve ekonomik yapısı üzerine bazı tespitler ve değerlendirmeler (1845). Çanakkale Araştırmaları Türk Yıllı$\breve{g} l, 24$ (16-Bahar): 289-320.

Orhun, M. (2018). Pergamon Kralı III. Attalos'un Bağışı ve Roma'nın Asya Eyaleti'nin Kuruluşu. Akademik Tarih ve Düşünce Dergisi, 5(14), 275-324

Özveri, Ü. (2005). İlkçağdaki Anadolu Halkları, Kafkas Dernekleri Yayın, https://www.kaffed.org/bilgi-belge/tarih/item/174-ilkcagdaki-anadoluhalklari.html adresinden erişilmiştir.

Polat Becks, B. A. (2015). Lamponeia und Topçakıllar: Zwei befestigte Höhensiedlungen der archaischen und klassischen Zeit bei Assos. K. Rheidt v.d. (Ed.). AssosKolloquium 15.-17. November 2012, 13-16.

Ramsay, W.R. (2015). V.Sevin, (Çev.). Anadolu'nun Tarihi Coğrafyası içinde 28 (Çev.), TTK Yayın. 
Ringas, D., Christopoulou, E., Stefanidakis, M. (2011). Urban Memory in Space and Time. G. Styliaras, D. Koukopoulos, F. Lazarinis (Ed.) Handbook of Research on Technologies and Cultural Heritage içinde 39-42. Information Science Reference.

Russell, P. (2007). Liverpool's Past: A magical mystery tour. The Mersey Sound: Liverpool's Language, People and Places, Open House Press, 17-35.

Skirbekk, N., Gilje, N. (2006). Antik Yunan'dan modern döneme felsefe tarihi. Kesit Yayınlar1, 39-44.

Strabon (2005) Antik Anadolu coğrafyası (Geographika) (Kitap XII, XII, XIV) A.Pekman (Çev.). Arkeoloji ve Sanat Yayınları, XII: 18-19

Sustainable Development (2020, 11 Mart). Transforming our world. https://sustainabledevelopment.un.org/content/documents/7891Transforming\%20 Our\%20World.pdf adresinden erişilmiştir.

Takaoğlu, T. (2007). Antik Lampsakos'lu Bilgin ve Düşünürler, Lapseki Sempozyumu, 23-24 Haziran 2007, 204-212.

Tanoğlu, M., Yücesan, M., ve Yağmur, İ. (2019). Lapseki Halkının 1915 Çanakkale köprüsüne bakışı ve beklentileri üzerine bir inceleme. ICOAEF VI-International Conference on Applied Economics and Finance and Extended With Social Sciences, 90-97.

Tenger, B. (1999). Zur Geographie und Geschichte der Troas. In E. Schwertheim (Hrsg.), DieTroas III., Neue Forschungen, 155.

Thorpe, M. (2002). Roma Mimarlı̆̆ı. R.Akbulut (Çev.). Homer Kitabevi.81.

Thukydides (1976). Peloponnesos Savaşı-M.Ö. 431-404. T. Gökçöl (Çev.). Hürriyet Yayınları, 19-20.

Tolun, V. (2012). Aşklar, savaşlar, kahramanlar ve Çanakkale; Osmanlı'nın Akdeniz'e açılan kapısı. F. Özdem (Ed.) Çanakkale içinde (s.11-162). Yapı Kredi Yayın.

Tuna, C. (2012). Pityussa-Lampsakos-Lapseki. Altan Basımevi, 140-280.

Türk, E., Gültekin, N. (2019). Arkeolojik mirasın çağdaş kente kazandırılması: Antakya Müze Otel, 5. Uluslararası Kültür ve Medeniyet Kongresi, 604-622.

Türker, A. Ç. (2006). Bizans Döneminde Orta Boğaz bölgesi ve Madytos. İ.G. Yumuşak (Ed.). Çanakkale I: Savaşı ve Tarihi içinde 39-41. İstanbul Büyükşsehir Belediyesi.

Türker, A.Ç. (2008). Çanakkale Boğazında Bizans dönemine ait tarihi ve arkeolojik veriler. M. Demir (Ed.). Çanakkale Tarihi Cilt-I içinde 526-530. Değişim Yayınları.

Türkiye Nüfusu İ İlçe Mahalle Nüfusları (2020, 05 Şubat). Lapseki Nüfusu Çanakkale, https://www.nufusune.com/lapseki-ilce-nufusu-canakkale adresinden erişilmiştir.

Umar, B. (1999) İlkçă̆da Türkiye Halkı. İstanbul: İnkılap Yayın, 21.

UNESCO (2017, 01 Ocak), World Heritage Centre and ICOMOS. https://whc.unesco.org/en/news/date=2017-01-01\&calendarmode=year adresinden erişilmiştir.

UNESCO-WHC (2015). Policy for the Integration of a Sustainable Development Perspective into the Processes of The World Heritage Convention.

United Nations (2012, 01 Haziran) Realizing the Future We Want for All, Erişim Adresi: http://www.un.org/millenniumgoals/pdf/Post_2015_UNTTreport.pdf adresinden erişilmiştir. 
Uysal, A.O. (2013). Osmanlı Devrinde Lapseki ve mimarlık eserleri. Sanat Tarihi Dergisi, 22 (2), 149-187.

Uzunçarşıll, İ.H. (1982). Osmanlı Tarihi. Cilt-I. (4.baskı), TTK. Yayın, 355.

Ünlü, T.S. (2017). Kent kimliğinin oluşumunda kentsel bellek ve kentsel mekân ilişkisi: Mersin örneği. Planlama, 27(1), 75-93

Yüksel, E. (2012). 17. yüzyıl Sonu, 18.yüzyıl Ortası ve 19.Yüzyıl Başında Yabancı Seyyahların Gözünden Batı Anadolu Antik Kentleri. Yayınlanmamış Y. Lisans Tezi, Adnan Menderes Üniversitesi Sosyal Bilimler Enstitüsü Tarih Anabilim Dalı. 30-36.

Yüksel, Y. (2010). Felsefe Tarihi metodolojisi II. İstanbul: İstanbul Üniversitesi Açık ve Uzaktan Eğitim Fakültesi Yayın. 23-28 